\title{
Pengujian Indikator Subjektif dan Okulomotor dalam Mendeteksi Kantuk dan Kelelahan: Eksperimen dengan Simulator Kereta Api
}

\author{
Clara Theresia
}

Fakultas Teknologi Industri, Jurusan Teknik Industri, Universitas Katolik Parahyangan e-mail korespondensi: claratheresia@ unpar.ac.id doi:https://doi.org/10.24843/JEI.2019.v05.i02.p02

Article Received: 18 Oktober 2019; Accepted: 30 Desember 2019; Published: 31 Desember 2019

\begin{abstract}
Abstrak
Kelelahan dan kantuk merupakan faktor yang berkontribusi terhadap kecelakaan khususnya disektor transportasi. Sejumlah pengukuran subjektif dan objektif dapat digunakan sebagai indikator pendeteksi kelelahan dan kantuk. Penelitian ini bertujuan untuk melakukan investigasi apakah terdapat korelasi antara Karolinska sleepiness Scale sebagai indikator kantuk subjektif terhadap frekuensi kedipan sebagai indikator okulomotor objektif dalam mendeteksi kelelahan dan kantuk. Penelitian ini melibatkan 12 orang partisipan yang mengemudikan simulator kereta api selama 4 jam perjalanan. Setiap partisipan mengalami tiga perlakuan kuantitas tidur pada malam sebelum eksperimen yaitu kondisi tidur ekstrim (2 jam), moderate (4 jam) dan normal (8 jam). Penilaian kelelahan dan kantuk menggunakan 2 indikator yaitu indikator kantuk subjektif dengan Karolinska Sleepiness Scale dan indikator pergerakan mata berupa frekuensi kedipan per menit dari rekaman video kamera sepanjang perjalanan. Temuan utama pada penelitian ini yaitu adanya korelasi positif kuat antara indikator kantuk subjektif terhadap indikator okulomotor berupa frekuensi kedipan per menit khususnya untuk kondisi tidur moderate 4 jam $(r=0.861, \mathrm{p}=0.013)$. Korelasi yang kuat antara keduanya menunjukkan bahwa kedua indikator baik subjektif maupun okulomotor dapat saling mendukung dalam mendeteksi kantuk dan kelelahan. Temuan lainnya bahwa skor KSS $>5$ terjadi setelah satu jam mengemudi untuk kondisi sleep deprivation ekstrim 2 jam dan terjadi setelah 160 menit mengemudi pada kondisi tidur moderate 4 jam.
\end{abstract}

Kata kunci: Karolinska Sleepness Scale, kedipan mata, kelelahan dan kantuk

\section{Subjective and Oculomotor Indicator for Detecting Fatigue and Drowsiness: Case study using Train Simulator}

\begin{abstract}
Fatigue and drowsiness are factors that contribute to accidents, especially in the transportation sector. A number of subjective and objective measurements can be used as indicators to detect fatigue and sleepiness. This study aims to investigate whether there is a correlation between the Karolinska sleepiness Scale as a subjective indicator of sleepiness and the frequency of blinking as an objective oculomotor. This study involved 12 participants who drove the train simulator for 4 hours. Each participant experienced three treatments of the quantity of sleep the night before the experiment namely extreme sleep conditions $(2 \mathrm{~h})$, moderate $(4 \mathrm{~h})$ and normal $(8 \mathrm{~h})$. Assessment of fatigue and sleepiness used 2 indicators, subjective indicators of sleepiness with the Karolinska Sleepiness Scale and indicators of eye movement in the form of the frequency of blinks per minute of video footage of the camera along the way. The main finding in this study was that there is a strong positive correlation between subjective sleepiness indicators and oculomotor indicators in blink rates per minute, especially for moderate sleep conditions of 4 hours $(r=0.861, p=0.013)$. A strong correlation between the two shows that both subjective and oculomotor can support each other in detecting
\end{abstract}


sleepiness and fatigue. Another finding is that a KSS score larger than 5 occurs after one hour of driving for 2 hours of extreme sleep deprivation and occurs after 160 minutes of driving in a moderate 4 hours sleep condition.

Keywords: Karolinska Sleepiness Scale, blink rate, fatigue and drowsiness

\section{PENDAHULUAN}

Kecelakaan kereta api erat dikaitkan dengan gangguan pada faktor manusia meliputi kelelahan serta kantuk yang mempengaruhi tingkat kewaspadaan dan performansi (Dorrian dkk., 2006). Berdasarkan hasil investigasi Komite Nasional Keselamatan Transportasi (KNKT) terjadi 35 kecelakaan dalam kurun waktu enam tahun terakhir (2010-2016). Selain di Indonesia, kecelakaan kereta api masih terjadi di negara maju seperti Inggris. Hasil investigasi menunjukkan bahwa 80 kecelakaan kereta api disebabkan oleh faktor manusia sebesar dengan persentase terbesar yaitu $53 \%$ dan persentase sisanya berasal dari faktor kesalahan teknis serta gangguan eksternal seperti rusaknya jalur kereta api (Kim dkk., 2015). Australia juga mengalami hal serupa, dimana 65\% dari total kecelakaan kereta api disebabkan oleh faktor kesalahan manusia (Baysari dkk., 2008).

Iridiastadi dan Ikatrinasari (2012) melakukan investigasi kecelakaan kereta api di Indonesia dengan pendekatan Human Factors Analysis and Classification System dan menemukan empat faktor utama penyebab kecelakaan. Faktor pada level pertama yaitu unsafe act sebesar 22\% dimana masinis cenderung mengabaikan sinyal lampu peringatan, mengubah jalur rute kereta api dan mengemudi tanpa ijin. Pre condition unsafe act merupakan level kedua dengan persentase terbesar yaitu 39\% meliputi kebosanan karena aktivitas mengemudi monoton, kelelahan dan kantuk yang dialami masinis. Faktor ketiga yaitu pengawasan atau supervisi sebesar $14 \%$ seperti penjadwalan shift kerja dan tidak adanya intervensi secara langsung jika terjadi kesalahan di kabin lokomotif. Faktor terakhir yaitu level organisasi sebesar $25 \%$ meliputi keterlambatan penjadwalan shift kerja dan informasi yang kurang lengkap mengenai aktivitas perawatan jalur dan sinyal kepada masinis kereta api.

Tidur merupakan hal yang penting bagi kesehatan tubuh manusia. Kondisi tidur yang kurang atau sleep deprivation akan mempengaruhi fungsi kognitif dan perilaku manusia serta meningkatkan resiko penyakit kronis seperti obesitas, gangguan hormonal dan gangguan fungsi kardiovaskular (Kryger dkk., 2016). Dalam jangka panjang, sleep deprivation dapat mengakibatkan terjadinya kantuk dan kelelahan kerja yang berujung pada penurunan tingkat kewaspadaan dan performansi mengemudi. Philip dan Akerstedt (2006) menyimpulkan bahwa performansi mengemudi yang menurun dalam jangka waktu yang panjang dapat menyebabkan terjadinya kecelakaan di sektor transportasi (misalnya terjadi pelanggaran batas kecepatan dan pelanggaran rambu lalu lintas).

Sejumlah indikator subjektif dan objektif dapat digunakan dalam mendeteksi kelelahan dan kantuk ketika mengemudi. Salah satu indikator subjektif yang banyak digunakan dan cukup efektif dalam mendeteksi kantuk yaitu Karolinska Sleepiness Scale (KSS) (Kaida, dkk., 2006; Kosmadopoulos, dkk., 2017). Indikator objektif yang biasa digunakan yaitu Psychomotor Vigilance Task (PVT) (Dawson, dkk., 2014; Theresia, dkk., 2018) terbukti cukup baik dalam mendeteksi penurunan tingkat kewaspadaan yang ditandai dengan melambatnya waktu respon terhadap stimulus. Dalam mendeteksi kantuk dan kelelahan, indikator mata atau okulomotor juga merupakan indikator yang dapat digunakan secara real time melalui rekaman video kamera. Penelitian Caffier, dkk. (2003) menyatakan bahwa parameter blink duration dan proporsi eye closure percentage cukup reliabel dalam mendeteksi kantuk dan kelelahan. Mahachandra, dkk. (2011) juga menyatakan bahwa pola 
kantuk dapat dideteksi dengan indikator subjektif KSS dan eye closure activity dalam penelitian terhadap 16 pengemudi mobil travel professional.

Penelitian ini bertujuan untuk menguji dan melakukan investigasi apakah terdapat korelasi yang baik antara indikator subjektif Karolinska Sleepiness Scale (KSS) dan indikator okulomotor (eye blink rate) secara real time melalui rekaman video kamera dalam mendeteksi kantuk dan kelelahan pada simulator kereta api. Temuan pada penelitian ini dapat digunakan untuk mendeteksi dan melakukan mitigasi terhadap kemungkinan terjadinya kelelahan dan kantuk yang berujung pada penurunan performansi mengemudi dan bisa mengakibatkan terjadinya kecelakaan disektor transportasi.

\section{METODE}

Penelitian ini menggunakan rancangan eksperimen within subject design dengan simulator kereta api di Laboratorium Fatigue, Institut Teknologi Bandung. Pada penelitian ini terdapat 3 level faktor perlakuan kuantitas tidur (durasi dalam jam) yaitu kondisi tidur normal 8 jam (K8), kondisi tidur moderate 4 jam (K4) dan kondisi tidur ekstrim 2 jam (K2). Pengukuran kuantitas tidur dilakukan dengan mengunakan smart watch (Fitbit Charge 2, Fitbit, Inc, USA). Fitbit digunakan pada malam hari sebelum eksperimen berlangsung dan pengecekan jumlah kuantitas tidur akan dilakukan di pagi hari sebelum eksperimen berlangsung. Penelitian ini melibatkan 12 orang partisipan pria dengan rata-rata usia 21 tahun $(\mathrm{SD}=0.953)$, sehat jasmani, kualifikasi pendidikan minimal D3 Teknik, tidak memiliki riwayat penyakit kronis, tidak merokok, tidak mengkonsumsi kafein selama proses eksperimen dan memiliki kemampuan untuk mengoperasikan PC/laptop. Partisipan dalam penelitian ini bukan masinis kereta api, namun demikian memiliki karakteristik sedekat mungkin dengan seorang masinis kereta api. Dalam penelitian Dunn dan Williamson (2012) membuktikan bahwa tidak terdapat perbedaan hasil performansi masinis dan non masinis dalam aktivitas mengemudi kereta api.

Penelitian menggenai aktivitas mengemudi kereta api tidak mudah untuk dilakukan di lapangan sehingga banyak penelitian sudah dilakukan dengan menggunakan simulator kereta api (Dorian,dkk 2007; Dunn dan Williamson, 2012). Penelitian ini menggunakan aplikasi software Railworks Trains Simulator (PI Engineering Software, Inc) versi 2015 yang diproduksi oleh Dovetail Games dengan tampilan visual yang dibantu oleh layar monitor TV LED 42 inch (LG Electronics, Indonesia) sebagai layar simulator, dan Rail Driver Desktop Cab Controller RD-91-MDT-R yang diproduksi oleh PI Engineering USA sebagai kontroler kereta api. Simulator kereta api dapat dilihat pada Gambar 1.

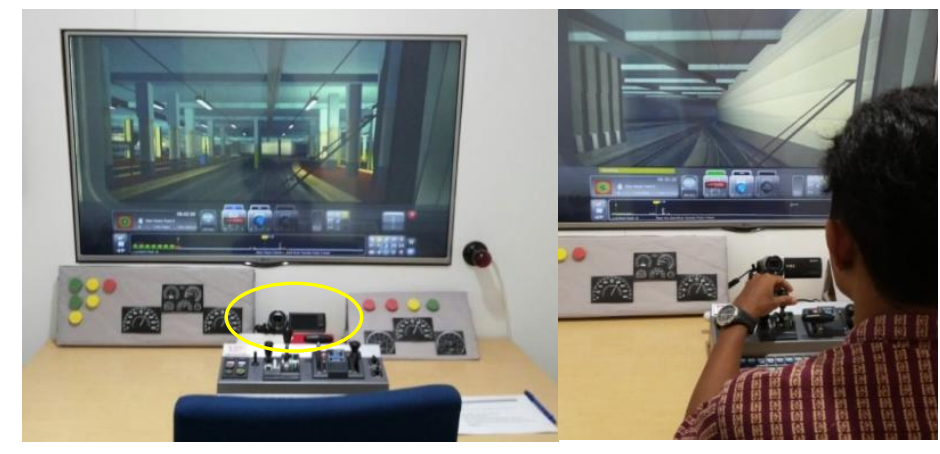

Gambar 1. Simulator Kereta Api di Laboratorium Fatigue

Skenario mengemudi kereta api disusun berdasarkan karakteristik kereta api jarak jauh yang bertujuan untuk mengantarkan penumpang dari satu kota ke kota lain dengan rute 
perjalanan yang lurus dan monoton (banyak pengulangan atau repetisi tugas dalam mengendalikan batas kecepatan). Pada skenario ini, partisipan diminta untuk mengemudikan simulator kereta api dengan durasi perjalanan selama 4 jam (pukul 08.00-12.00). Batas kecepatan maksimal yang dapat ditempuh dalam perjalanan ini adalah $75 \mathrm{~km} / \mathrm{jam}$ dengan batas kecepatan minimal $15 \mathrm{~km} / \mathrm{jam}$.

Penelitian ini menggunakan dua indikator pengujian kelelahan dan kantuk yaitu indikator subjektif berupa kuesioner Karolinska Sleepiness Scale (KSS) dan indikator objektif dari parameter kedipan mata atau blink rate yang dideteksi dengan video kamera yang dipasang di depan partisipan selama mengemudi. KSS merupakan indikator subjektif untuk mengukur tingkat kantuk pada waktu tertentu dalam rentang waktu yang telah ditentukan. KSS terdiri dari 9 titik skala dimana masing-masing partisipan harus memilih salah satu skala yang merepresentasikan keadaannya pada saat itu (Akerstedt dan Gilbert, 1990; Kaida dkk., 2006; Kosmadopoulos dkk., 2017). Pengisian kuesioner KSS dilakukan sejumlah 15 kali pengisian dengan perincian 1 kali di fase awal dan 1 kali di fase akhir eksperimen serta 13 kali selama proses simulasi dengan interval pengisian 20 menit. Parameter okulomotor yang diujikan pada penelitian ini adalah frekuensi kedipan per 5 menit atau blink rate. Schleicher dkk. 2008 menyimpulkan bahwa kelelahan dan kantuk erat kaitannya terhadap peningkatan frekuensi kedipan mata dan menjadi parameter terbaik dalam mendeteksi kelelahan akibat kantuk. Pada eksperimen ini aktivitas mata direkam dengan menggunakan video kamera (Sony Indonesia. Inc, Indonesia) yang dipasang di ruang simulator selama aktivitas mengemudi (dapat dilihat lingkaran kuning pada Gambar 1). Rekaman data pada video digunakan untuk menghitung kedipan mata atau eye blink dari partisipan selama menggunakan simulator kereta api.

Pengujian statistika dilakukan berdasarkan data performansi subjektif (skor kuesioner KSS) dan indikator okulomotor (frekuensi kedipan) dari hasil eksperimen dengan pengujian statistika deskriptif (nilai rataan dan standar deviasi), pengujian normalitas data dengan Uji Kolmogorov Smirnov. Pengujian korelasi dengan Pearson product moment dari indikator subjektif penilaian kantuk KSS terhadap frekuensi kedipan data yang diperoleh dari rekaman video kamera.

\section{HASIL DAN PEMBAHASAN}

Hasil pengisian kuesioner KSS menunjukkan bahwa rata-rata partisipan kondisi K2 berada pada skor KSS lebih dari 5 (neither alert nor sleepy) dimulai sekitar 60 menit setelah eksperimen berlangsung sedangkan kondisi K4 skor KSS lebih dari 5 dimulai setelah 160 menit eksperimen. Hasil skor KSS dapat dilihat pada Gambar 2.

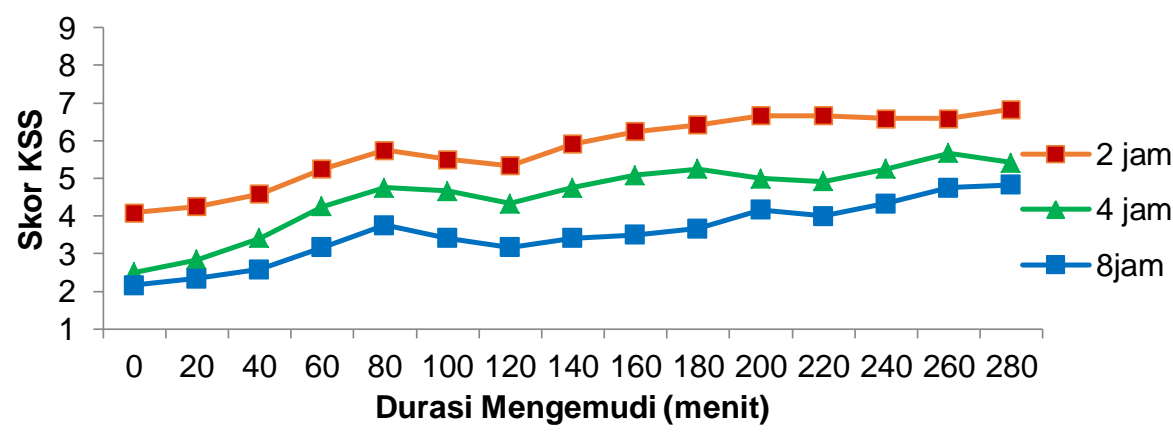

Gambar 2. Hasil KSS perbandingan kuantitas tidur 2, 4 dan 8 jam 
KSS untuk kondisi K8 diawal eksperimen menunjukkan angka 2 dan mendekati 5 di akhir eksperimen. Sebaliknya, KSS pada kondisi K2 menunjukkan posisi awal di angka 4 dan 7 di akhir eksperimen. Secara keseluruhan, KSS menunjukkan peningkatan skor sejumlah $41 \%$ bila dibandingkan antara kondisi K2 (Rerata=2,3; $\mathrm{SB}=0,3$ ) dan K8 (Rerata=7,79; $\mathrm{SB}=$ 0,58), dengan rerata KSS tertinggi pada angka 7 pada pukul 11.00, 11.40 dan 12.00 (Gambar 2).

Indikator subjektif pada penelitian ini menunjukkan adanya peningkatan yang linear pada nilai skor KSS terhadap waktu mengemudi kereta api dimana untuk kondisi K2 skor KSS berawal dari nilai 4 dan semakin meningkat sampai pada akhir eksperimen di nilai 7 untuk aktivitas mengemudi dengan simulator kereta api selama 4 jam. Bila dibandingkan dengan kondisi tidur yang normal terdapat peningkatan skor KSS dua kali lipat dari kondisi kurang tidur. Pada kondisi kuantitas tidur ekstrim (K2) skor KSS $>5$ dimulai setelah 1 jam eksperimen berlangsung sedangkan pada kuantitas tidur moderate (K4) skor KSS $>5$ dimulai setelah 160 menit eksperimen. Hal sebaliknya terjadi untuk kondisi tidur normal (K8) skor KSS $<5$. Hal ini sejalan dengan penelitian Pauly dan Shankar (2015) yang menyimpulkan bahwa skor KSS > 5 untuk partisipan dalam kondisi kantuk yang tinggi.

Penelitian Schleicher, dkk. (2008) juga menujukkan adanya penurunan tingkat kewaspadaan yang sebanding dengan peningkatan kantuk pada aktivitas mengemudi selama 2 jam. Selain itu, kurangnya kuantitas tidur bahkan hanya satu malam saja akan menurunkan skor penilaian subjektif, emosi dan mood seseorang bila di bandingkan dengan kondisi tidur normal 8 jam. Disimpulkan bahwa kurangnya kuantitas tidur akan mengakibatkan peningkatan pada indikator subjektif penilaian kantuk yang berujung pada penurunan performansi mengemudi.

Pengambilan data jumlah kedipan mata per 5 menit dilakukan selama 4 jam aktivitas mengemudi dengan simulator kereta api. Pengujian normalitas data dengan Uji Kolmogrov Smirnov dengan parameter blink rate $(Z=0,516 ; \mathrm{p}=0,476)$ dengan kuantitas tidur 2 jam, $(Z=1,008 ; \mathrm{p}=0,1305)$ untuk kuantitas tidur 4 jam dan $(Z=1,153 ; \mathrm{p}=0,07)$ kuantitas tidur 8 jam. Hasil pengujian menunjukkan bahwa data jumlah kedipan mata berdistribusi normal untuk ketiga kondisi kuantitas tidur. Hasil data frekuensi kedipan per menit pada 3 perlakuan kondisi tidur dapat dilihat pada Gambar 3.

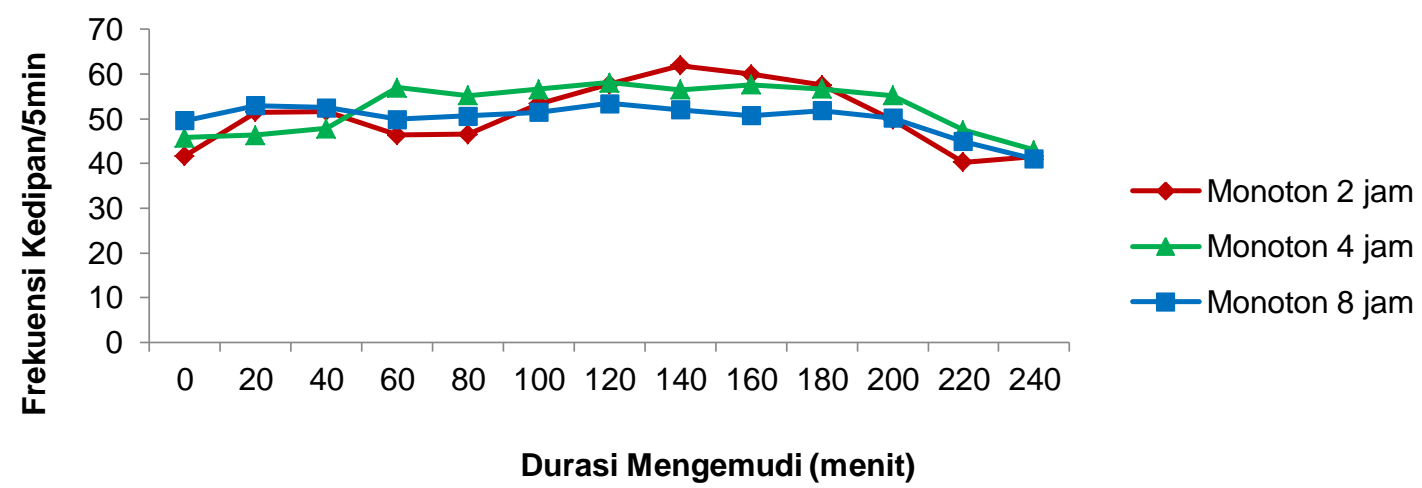

Gambar 3

Data Frekuensi Kedipan per Menit

Ketika mengalami sleep deprivation extreme (K2) terjadi peningkatan frekuensi kedipan mata yaitu 8 kedipan/menit (pukul 08.00) dan meningkat menjadi 12 kedipan/menit (pukul 10.20). Ketika aktivitas mengemudi simulator sudah berjalan dari 120-240 menit (pukul 10.20-12.00), skor KSS cenderung meningkat secara linear tetapi jumlah kedipan menurun, hal ini disebabkan karena partisipan mengalami peningkatan fase kantuk seiring 
dengan meningkatnya durasi mengemudi (Gambar 4). Temuan ini sejalan dengan penelitian Mahachandra, dkk. (2011) yang mengemukakan bahwa frekuensi kedipan per menit cukup sensitif dalam mendeteksi kantuk melalui indikator penilaian kantuk yang subjektif.

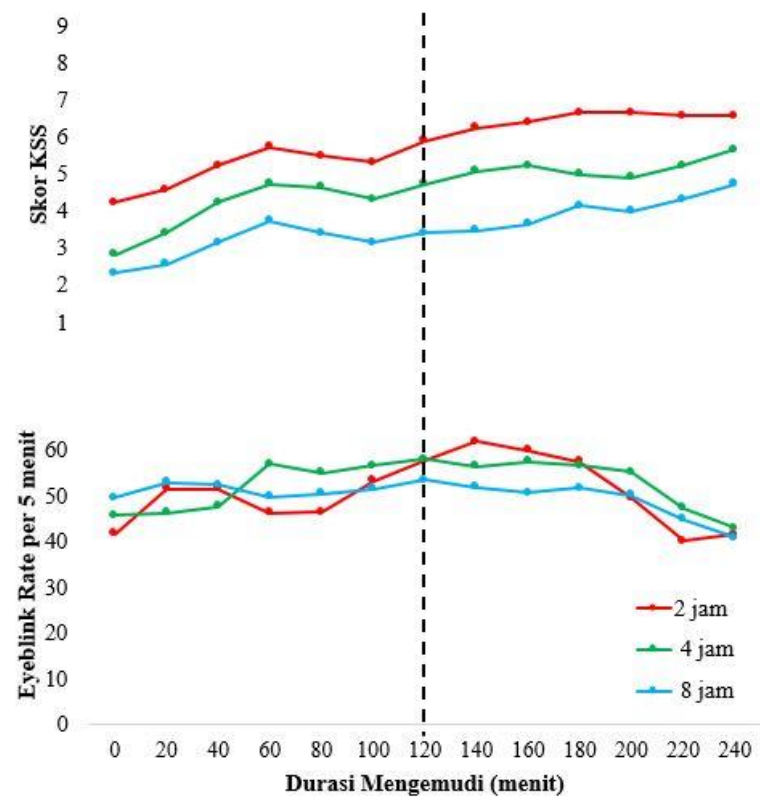

Gambar 4. Data Frekuensi Kedipan Mata dan Skor KSS

Data jumlah kedipan mata dan skor KSS dibagi kedalam 2 fase yaitu fase pertama (pukul 08.00-10.00) dan fase kedua (pukul 10.20-12.00). Selanjutnya diuji korelasi dengan pearson moment product antara jumlah kedipan mata dengan skor KSS sesuai dengan pembagian fase. Hasil pengujian korelasi pada fase pertama dapat dilihat pada Tabel 1.

Tabel 1

Korelasi Jumlah Kedipan Mata dengan Skor KSS Fase Pertama

\begin{tabular}{|c|c|c|c|c|c|c|c|}
\hline & & ER_2jam & ER_4jam & ER_8jam & KSS_2jam & KSS_4jam & KSS_8jam \\
\hline \multirow{3}{*}{ ER_2jam } & $\begin{array}{l}\text { Pearson } \\
\text { Correlation }\end{array}$ & 1 & 0.353 & $0.885^{* *}$ & 0.373 & 0.244 & 0.217 \\
\hline & $p$ (2-tailed) & & 0.438 & 0.008 & 0.41 & 0.599 & 0.64 \\
\hline & $\mathrm{N}$ & 7 & 7 & 7 & 7 & 7 & 7 \\
\hline \multirow{3}{*}{ ER_4jam } & $\begin{array}{l}\text { Pearson } \\
\text { Correlation }\end{array}$ & 0.353 & 1 & -0.091 & $0.767 *$ & $0.861^{*}$ & 0.577 \\
\hline & $p$ (2-tailed) & 0.438 & & 0.846 & 0.044 & 0.013 & 0.175 \\
\hline & $\mathrm{N}$ & 7 & 7 & 7 & 7 & 7 & 7 \\
\hline \multirow{3}{*}{ ER_8jam } & $\begin{array}{l}\text { Pearson } \\
\text { Correlation }\end{array}$ & $0.885^{* *}$ & -0.091 & 1 & 0.091 & -0.096 & 0.000 \\
\hline & $p$ (2-tailed) & 0.008 & 0.846 & & 0.846 & 0.838 & 1 \\
\hline & $\mathrm{N}$ & 7 & 7 & 7 & 7 & 7 & 7 \\
\hline \multirow{3}{*}{ KSS_2jam } & $\begin{array}{l}\text { Pearson } \\
\text { Correlation }\end{array}$ & 0.373 & $0.767 *$ & 0.091 & 1 & $0.91 * *$ & $0.764 *$ \\
\hline & $p$ (2-tailed) & 0.41 & 0.044 & 0.846 & & 0.004 & 0.046 \\
\hline & $\mathrm{N}$ & 7 & 7 & 7 & 7 & 7 & 7 \\
\hline KSS_4jam & Pearson & 0.244 & $0.861^{*}$ & -0.096 & $0.91 * *$ & 1 & 0.642 \\
\hline
\end{tabular}


ER_2jam ER_4jam ER_8jam KSS_2jam KSS_4jam KSS_8jam

\begin{tabular}{rlcccccc}
\hline Correlation & & & & & & \\
& $p$ (2-tailed) & 0.599 & 0.013 & 0.838 & 0.004 & & 0.12 \\
$\mathrm{~N}$ & 7 & 7 & 7 & 7 & 7 & 7 \\
& Pearson & 0.217 & 0.577 & 0.000 & $0.764 *$ & 0.642 & 1 \\
KSS_8jam & Correlation & & & & & \\
& $p$ (2-tailed) & 0.64 & 0.175 & 1 & 0.046 & 0.12 & \\
& $\mathrm{~N}$ & 7 & 7 & 7 & 7 & 7 & 7 \\
\hline
\end{tabular}

* Correlation is significant at the 0.05 level (2-tailed)

** Correlation is significant at the 0.01 level (2-tailed)

$E R=$ Eyeblink rates $;$ KSS = Karolinska Sleepiness Scale

Pada fase pertama (pukul 08.00-10.00) korelasi yang signifikan $(p<0,05)$ hanya terjadi antara jumlah kedipan mata dan skor KSS untuk kondisi K4 dengan nilai $r=0,861$ (nilai $\mathrm{p}=0,013$ ) sedangkan untuk kondisi $\mathrm{K} 2$ hanya berkorelasi dengan nilai $r=0,373$. Hasil sebaliknya terjadi pada fase kedua yang dapat dilihat pada Tabel 2.

Tabel 2

Korelasi Jumlah Kedipan Mata dengan Skor KSS Fase Kedua

\begin{tabular}{|c|c|c|c|c|c|c|c|}
\hline & & ER_2jam & ER_4jam & ER_8jam & KSS_2jam & KSS_4jam & KSS_8jam \\
\hline \multirow{3}{*}{ ER_2jam } & $\begin{array}{l}\text { Pearson } \\
\text { Correlation }\end{array}$ & 1 & $0.92 * *$ & $0.893 * *$ & -0.748 & -0.536 & -0.517 \\
\hline & $p$ (2-tailed) & & 0.003 & 0.007 & 0.053 & 0.215 & 0.235 \\
\hline & $\mathrm{N}$ & 7 & 7 & 7 & 7 & 7 & 7 \\
\hline \multirow{3}{*}{ ER_4jam } & $\begin{array}{l}\text { Pearson } \\
\text { Correlation }\end{array}$ & $0.92 * *$ & 1 & $0.987 * *$ & -0.633 & $-0.77 *$ & -0.716 \\
\hline & $p$ (2-tailed) & 0.003 & & 0.000 & 0.127 & 0.043 & 0.071 \\
\hline & $\mathrm{N}$ & 7 & 7 & 7 & 7 & 7 & 7 \\
\hline \multirow{3}{*}{ ER_8jam } & $\begin{array}{l}\text { Pearson } \\
\text { Correlation }\end{array}$ & $0.893 * *$ & 0.987 & 1 & -0.6 & $-0.807^{*}$ & $-0.778^{*}$ \\
\hline & $p$ (2-tailed) & 0.007 & 0.000 & & 0.154 & 0.028 & 0.039 \\
\hline & $\mathrm{N}$ & 7 & 7 & 7 & 7 & 7 & 7 \\
\hline \multirow{3}{*}{ KSS_2jam } & $\begin{array}{l}\text { Pearson } \\
\text { Correlation }\end{array}$ & -0.748 & -0.633 & -0.6 & 1 & 0.354 & 0.54 \\
\hline & $p$ (2-tailed) & 0.053 & 0.127 & 0.154 & & 0.437 & 0.211 \\
\hline & $\mathrm{N}$ & 7 & 7 & 7 & 7 & 7 & 7 \\
\hline \multirow{3}{*}{ KSS_4jam } & $\begin{array}{l}\text { Pearson } \\
\text { Correlation }\end{array}$ & -0.536 & $-0.77 *$ & $-0.807 *$ & 0.354 & 1 & $0.764 *$ \\
\hline & $p$ (2-tailed) & 0.215 & 0.043 & 0.028 & 0.437 & & 0.046 \\
\hline & $\mathrm{N}$ & 7 & 7 & 7 & 7 & 7 & 7 \\
\hline \multirow[t]{3}{*}{ KSS_8jam } & $\begin{array}{l}\text { Pearson } \\
\text { Correlation }\end{array}$ & -0.517 & -0.716 & $-0.778 *$ & 0.54 & $0.764^{*}$ & 1 \\
\hline & $p$ (2-tailed) & 0.235 & 0.071 & 0.039 & 0.211 & 0.046 & \\
\hline & $\mathrm{N}$ & 7 & 7 & 7 & 7 & 7 & 7 \\
\hline
\end{tabular}

* Correlation is significant at the 0.05 level (2-tailed)

** Correlation is significant at the 0.01 level (2-tailed)

$E R=$ Eyeblink rates $;$ KSS $=$ Karolinska Sleepiness Scale 
Pada fase kedua (pukul 10.20-12.00) terjadi korelasi yang signifikan $(p<0,05)$ antara jumlah kedipan mata dengan skor KSS untuk kondisi K4 $(r=0,770 ; \mathrm{p}=0,043)$ dan kuantitas tidur 8 jam $(r=0,778 ; \mathrm{p}=0,039)$. Disimpulkan bahwa terjadi korelasi yang lebih kuat pada fase kedua dari aktivitas mengemudi dengan simulator kereta api.

Hasil performansi mengemudi pada simulator kereta api dapat dilihat pada peningkatan jumlah pelanggaran batas kecepatan atau speeding error. Performansi mengemudi tersebut dapat dilihat pada Gambar 5.

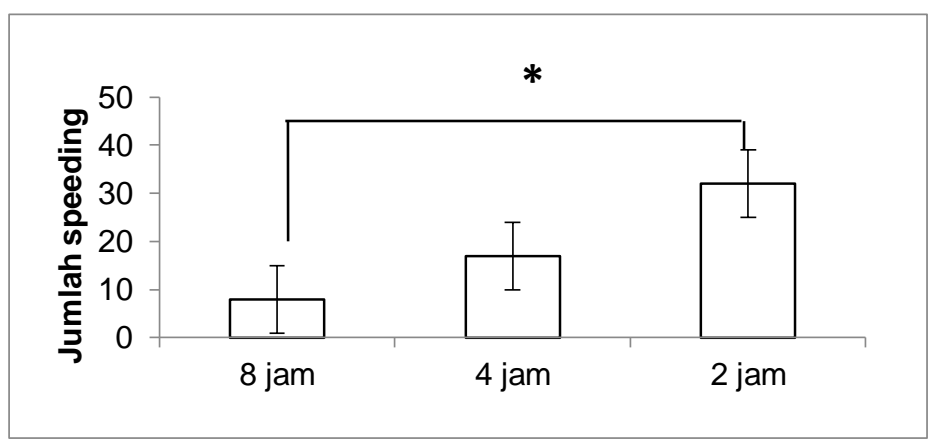

Gambar 5. Hasil Performansi Mengemudi dengan Simulator kereta api

Parameter yang digunakan untuk mengetahui performansi partisipan ketika mengemudi dengan simulator kereta api adalah jumlah kesalahan pelanggaran batas kecepatan. Hasil eksperimen menunjukkan bahwa terdapat $75 \%$ peningkatan jumlah pelanggaran batas kecepatan mengemudi antara kondisi tidur normal (Rerata $=8$; $\mathrm{SB}=5,25$ ) dengan kuantitas tidur ekstrim (Rerata=32; SB=14,98). Selain itu terdapat peningkatan jumlah pelanggaran batas kecepatan sebesar 53\% bila dibandingkan antara kuantitas tidur normal 8 jam dengan kuantitas tidur moderate (Rerata $=18$ jam; $\mathrm{SB}=4.5$ ).

Pengujian normalitas data dengan Uji Kolmogrov Smirnov dengan parameter speeding error $(Z=0,604 ; p=0,429)$ dengan kuantitas tidur 2 jam, $(Z=0,571 ; p=0,450)$ untuk kuantitas tidur 4 jam dan $(Z=0,389$; $\mathrm{p}=0,499)$ kuantitas tidur 8 jam. Hasil pengujian menunjukkan bahwa data jumlah pelanggaran batas kecepatan berdistribusi normal untuk ketiga kondisi kuantitas tidur. Pengujian ANOVA pada parameter speeding error menunjukkan adanya perbedaan signifikan antara hasil speeding error terhadap kondisi tidur partisipan selama eksperimen $(F(2,22)=37,9 ; \mathrm{p}=0,001)$ yang artinya ada perbedaan signifikan antara hasil pengujian parameter speeding error terhadap kuantitas tidur partisipan selama eksperimen. Selanjutnya dilakukan post hoc test dengan Uji Bonferroni dan diperoleh hasil bahwa pelanggaran batas kecepatan pada kondisi K2 dan K8 berbeda dengan signifikansi terbesar bila dibandingkan dengan $\mathrm{K} 4$.

\section{SIMPULAN}

Hasil temuan utama pada penelitian ini yaitu terdapat korelasi positif kuat antara indikator kantuk subjektif terhadap indikator okulomotor berupa frekuensi kedipan per menit khususnya untuk kondisi tidur moderate 4 jam $(r=0,861 ; \mathrm{p}=0.013)$. Korelasi ini menunjukkan bahwa indikator subjektif dan okulomotor dapat saling mendukung dalam mendeteksi kantuk dan kelelahan. Hasil temuan lainnya bahwa skor KSS yang lebih dari 5 terjadi setelah satu jam mengemudi untuk kondisi tidur ekstrim 2 jam dan terjadi setelah 160 menit mengemudi pada kondisi tidur moderate 4 jam. Pada penelitian ini terdapat sejumlah keterbatasan yaitu pengukuran kecukupan tidur partisipan hanya berdasarkan pada kuantitas atau jumlah durasi tidur bukan berdasarkan sleep efficiency atau kualitas 
tidur. Beberapa penelitian terkait menemukan fakta bahwa kuantitas tidur yang cukup 7-8 jam belum tentu memiliki kualitas tidur yang baik pula. Perbaikan untuk penelitian selanjutnya adalah menggunakan indikator sleep efficiency dalam menentukan standar tidur dari partisipan.

\section{DAFTAR PUSTAKA}

Akerstedt, T dan Gilberg, M. 1990. Subjective and objective sleepiness in active individual. International Journal Neuroscience, Vol. 52(1-2):29-37. https://www.tandfonline.com/doi/abs/10.3109/00207459008994241

Baysari, M. T, Mc Intosh A. S., Wilson, J. R. 2008. Understanding the human factors contribution to railways accidents and incidents in Australia. Accident Analysis Prevention, Vol. 40:1750-1757.

Caffier, P.P., Erdmann, U., Ullsperger, P. 2003. Experimental evaluation of eye-blink parameters as a drowsiness measure. European Journal Applied Physiology, Vol. 89(34):319-325.

Craig, A., Tran, Y., Wijesuriya, N. 2011. Psychophysiological Characteristics of Driver Fatigue. In Joris C Verster and Charles F P George (Eds.), Sleep, Sleepiness and Traffic Safety. New York: Nova Science Publishers. pp. 65-91.

Dawson, D., Searle, A. K., Paterson, J. L. 2014. Look before you (s)leep: Evaluating the use of fatigue detection technologies within a fatigue risk management system for the road transport industry. Sleep Medicine Review, Vol.18:141-152.

Dorrian, J., Hussey, F., Dawson, D. 2007. Train driving efficiency and safety: examining the cost of fatigue. Journal of Sleep Research, Vol. 16:1-11. https://www.ncbi.nlm.nih.gov/pubmed/17309757

Dunn, $\mathrm{N}$ dan Williamson, A. 2012. Driving monotonous routes in train simulator: the effect of task demand on driving performance and subjective experience. Ergonomics, Vol. 55:997-1008.

https://www.tandfonline.com/doi/abs/10.1080/00140139.2012.691994?journalCode=ter g20

Iridiastadi, H dan Ikatrinasari, ZF. 2012. Indonesian railway accidents utilizing Human Factors Analysis and Classification system in determining potential contributing factors. Work, Vol. 41(1):4246-4249.

Kaida, K., Takahashi, M., Akerstedt, T., Nakata, A., Otsuka, Y., Haratani, T., Fukusawa, K. 2006. Validation of the karolinska sleepiness scale against performance and EEG variables. Clinical Neurophysiology, Vol. 117(7):1574-1581. https://doi.org/10.1016/j.clinph.2006.03.011

Kim, D.S. dan Yoon, W.C. 2013. Accident causation model for railway industry: application of the model to 80 rail accident investigation reports from the UK. Safety Science. Vol. 60:57-68.

Komite Nasional Keselamatan Transportasi. 2016. Data Investigasi Kecelakaan Perkeretaapian Tahun 2010-2016. Database KNKT, 31 Oktober 2016.

Kosmadopoulos, A., Sargent, C., Zhou, X., Darewent, D., Matthews, R,W., Dawson, D., Roach, G, D. 2017. The efficacy of objective and subjective predictors of driving performance during sleep restriction and circadian misalignment. Accident Analysis and Prevention, Vol. 1(99):445-451.

Kryger, M., Roth, T., Dement, W.C. 2016. Principles and practice of sleep medicine. Sixth Edition. Philadelphia: Elsevier, Chapter 2 pp.19-21.

Lal, S. K. L. dan Craig, A. A. 2001. Critical review of the psychophysiology of driver fatigue, Biological Psychology, Vol. 55:173-194. https://doi.org/10.1016/S0301$\underline{0511(00) 00085-5}$ 
Mahachandra, M., Yassierli, Sutalaksana, I. Z., Suryadi, K. 2011. Sleepiness patern of Indonesian professional driver based on subjective scale and eye closure activity, International Journal of Basic and Applied Sciences, Vol. 11(6):87-96.

Pauly, L., dan Shankar, D. 2015. Detection of Drowsiness based on HOG features and SVM classifiers. Proceedings of IEEE International Conference on Computer Graphics, Vision and Information Security (CGVIS)

Philip, P dan Akerstedt, T. 2006. Transport and industrial safety How they affected by sleepiness and sleep restriction. Sleep Medicine Review, Vol. 10(5):347-356. https://doi.org/10.1016/j.smrv.2006.04.002

Schleicher, R., Galley, N., Briest, S., Galley, N. 2008. Blink and saccades as indicator of fatigue in sleepiness warning: looking tired? Ergonomic, Vol. 51(7):982-1010. https://doi.org/10.1080/00140130701817062

Theresia, C., Iridiastadi, H., Pratama, G.B. 2018. Impact of sleep deprivation on vigilance, fatigue and performance during simulated train driving. Proceedings of the $2^{\text {nd }}$ International Conference on High Performance and Compilation, Computing and Communications. Hong Kong: ACM Publishers, pp 45-50. 